Article

\title{
Exposure to the Insecticide Sulfoxaflor Affects Behaviour and Biomarkers Responses of Carcinus maenas (Crustacea: Decapoda)
}

\author{
Jadilson M. Damasceno ${ }^{1}$, Lénia D. Rato ${ }^{1,2}{ }^{\text {, Tiago Simões }}{ }^{1}{ }^{\mathbb{D}}$, Inês F. C. Morão ${ }^{1}{ }^{\mathbb{C}}$, Gabriela Meireles ${ }^{1}$, \\ Sara C. Novais $1, *(\mathbb{D}$ and Marco F. L. Lemos $1, * \mathbb{D}$ \\ 1 MARE-Marine and Environmental Sciences Centre, ESTM, Polytechnic of Leiria, 2520-630 Peniche, Portugal; \\ jadilson.damasceno@ipleiria.pt (J.M.D.); lenia.rato@ipleiria.pt (L.D.R.); tiago.simoes@ipleiria.pt (T.S.); \\ ines.morao@ipleiria.pt (I.F.C.M.); gabriela.meireles@ipleiria.pt (G.M.) \\ 2 Department of Coastal Systems, NIOZ-Royal Netherlands Institute for Sea Research, 't Horntje, \\ 1797 SZ Texel, The Netherlands \\ * Correspondence: sara.novais@ipleiria.pt (S.C.N.); marco.lemos@ipleiria.pt (M.F.L.L.)
}

check for updates

Citation: Damasceno, J.M.; Rato, L.D.; Simões, T.; Morão, I.F.C.; Meireles, G.; Novais, S.C.; Lemos, M.F.L. Exposure to the Insecticide Sulfoxaflor Affects Behaviour and Biomarkers Responses of Carcinus maenas (Crustacea: Decapoda). Biology 2021, 10, 1234. https:// doi.org/10.3390/biology10121234

Academic Editor: Natraj Krishnan

Received: 15 October 2021

Accepted: 24 November 2021

Published: 26 November 2021

Publisher's Note: MDPI stays neutral with regard to jurisdictional claims in published maps and institutional affiliations.

Copyright: (C) 2021 by the authors Licensee MDPI, Basel, Switzerland. This article is an open access article distributed under the terms and conditions of the Creative Commons Attribution (CC BY) license (https:/ / creativecommons.org/licenses/by/ $4.0 /)$.
Simple Summary: Sulfoxaflor is an insecticide for which there are few studies regarding its toxicity to non-target organisms. The present study aimed to investigate the acute and sub-lethal effects of sulfoxaflor on Carcinus maenas by addressing survival, behaviour, and biomarkers. Sulfoxaflor affected feed intake and motricity of $C$. maenas. From the integrated analysis of endpoints, with the increase in concentrations of sulfoxaflor, after seven days, one can notice a lower detoxification capacity, higher lipid peroxidation, and higher motricity effects and lower feed intake. This study aims to contribute to the understanding of the negative impacts of sulfoxaflor on green crabs and increase knowledge of this pesticide toxicity to non-target coastal invertebrates.

\begin{abstract}
Sulfoxaflor is an insecticide belonging to the recent sulfoximine class, acting as a nicotinic acetylcholine receptor (nAChRs) agonist. There are few studies regarding sulfoxaflor's toxicity to non-target organisms. The present study aimed to investigate the acute and sub-lethal effects of sulfoxaflor on Carcinus maenas by addressing survival, behaviour (feed intake and motricity), and neuromuscular, detoxification and oxidative stress, and energy metabolism biomarkers. Adult male green crabs were exposed to sulfoxaflor for $96 \mathrm{~h}$ and an $\mathrm{LC}_{50}$ of $2.88 \mathrm{mg} \mathrm{L}^{-1}$ was estimated. All biomarker endpoints were sampled after three (T3) and seven (T7) days of exposure and behavioural endpoints were addressed at T3 and day six (T6). Sulfoxaflor affected the feed intake and motricity of C. maenas at T6. From the integrated analysis of endpoints, with the increase in concentrations of sulfoxaflor, after seven days, one can notice a lower detoxification capacity (lower GST), higher LPO levels and effects on behaviour (higher motricity effects and lower feed intake). This integrated approach proved to be valuable in understanding the negative impacts of sulfoxaflor on green crabs, while contributing to the knowledge of this pesticide toxicity to non-target coastal invertebrates.
\end{abstract}

Keywords: coastal invertebrates; crab; ecotoxicology; energy metabolism; neurotoxicity; oxidative stress; pesticide

\section{Introduction}

Aquatic pollution is a major concern due to its detrimental effects in biota. Agriculture is one of the main sources of water pollution through the run-off of metals, pathogens, nutrients, and pesticides [1].

Economic loss in agriculture, namely caused by insect pests, requires the application of pesticides [2]. Different classes of pesticides, each with a particular mode of action (MoA), have proven to be useful in the control of various sap-feeding insects [3,4]. However, the high production rate and indiscriminate use of these chemicals has raised concerns about the contamination of ecosystems, due to their toxicity to organisms and persistence in the environment [5-7]. 
Sulfoxaflor, methyl(oxo)\{1-[6-(trifluoromethyl)-3-pyridyl]ethyl\}- $\Lambda^{6}$-sulfanylidene) cyanamide, is an insecticide developed by Dow AgroSciences [8], classified in the sulfoximines class, used in the control of a wide range of insect strains that have demonstrated resistance to other pesticides, including neonicotinoids $[4,9,10]$. Sulfoxaflor's (Isoclast ${ }^{\mathrm{TM}}$ active) mode of action consists of an agonist interaction between pesticides with nicotinic acetylcholine receptors (nAChRs), acting as an activator $[4,8]$ through contact or ingestion. Thus, sulfoxaflor targets the nervous system, causing excitatory symptoms, namely tremors, leg extension or curling, partial or complete paralysis and mortality, as observed in studies carried out with insects [4,11]. Due to some similarities in the mode of action between other neonicotinoids and sulfoxaflor, there are concerns about sulfoxaflor's possible effects on non-target organisms [4,12]. Indeed, a very limited number of studies are available about sulfoxaflor non-targeted toxicity [13]. Sulfoxaflor, under field conditions in soil, has a half-life $\left(\mathrm{DT}_{50}\right)$ average of four days. However, the $\mathrm{DT}_{50}$ in the sediment/aquatic systems can range between 37 and 88 days [8].

To understand how the new generation pesticide sulfoxaflor affects non-target organisms in coastal/marine environments, an ecotoxicological approach using the European green crab Carcinus maenas as a non-target model species was performed, recurring to biomarker responses [14]. Crustaceans, due to their wide distributions, sedentary life-style, and relative tolerance to contaminants, are model organisms commonly used to assess the quality of aquatic ecosystems, as reviewed in Lionetto et al. [14]. Carcinus maenas has been extensively studied for more than 45 years, being proposed as a suitable model species in ecotoxicology, while also having a significant ecological relevance [15] and being economically important in some regions, as reviewed in Klassen and Locke [16] and Young and Elliott [17].

In this context, this study investigated acute and sub-lethal exposure to sulfoximinebased insecticide sulfoxaflor on the non-target coastal $C$. maenas, interconnecting different levels of biological organisation, namely the survival, behaviour (feed intake and motricity), and biomarker responses. When a xenobiotic enters the organism's body, detoxification mechanisms are activated. This involves two phases of biotransformation [18,19]. In Phase I, a functional group is introduced into the lipophilic contaminant chemical structure, increasing their polarity, and in Phase II small molecules, such as glutathione (GSH), are conjugated with the xenobiotics by enzymes (e.g., glutathione-S-transferase-GST), increasing their solubility for elimination [18-20]. By interfering with the redox cycling, this detoxification process can also potentiate the production of reactive oxygen species (ROS) [21-23], which is already naturally occurring due to the metabolic activity and energy production involving molecular oxygen $\left(\mathrm{O}_{2}\right)$ [24]. The most commonly evaluated ROS are the superoxide anion $\left(\mathrm{O}_{2-}\right)$, hydroxyl radical $(\mathrm{HO} \bullet)$, hydrogen peroxide $\left(\mathrm{H}_{2} \mathrm{O}_{2}\right)$, and singlet oxygen $\left({ }^{1} \mathrm{O}_{2}\right)[24,25]$. To prevent adverse effects, there are antioxidant enzymes and low molecular weight scavengers responsible for removing these oxyradicals [22,25], such as the superoxide dismutase (SOD) enzyme, which produces $\mathrm{H}_{2} \mathrm{O}_{2}$ during dismutation of $\mathrm{O}_{2}{ }^{-}$, followed by catalase (CAT) and glutathione peroxidase (GPx) enzymes, that convert $\mathrm{H}_{2} \mathrm{O}_{2}$ into $\mathrm{H}_{2} \mathrm{O}[24,26,27]$. Nonetheless, high quantities of $\mathrm{ROS}$ can overcome the defensive mechanisms and cause oxidative damage in macromolecules such as lipids, proteins, and DNA [21]. To cope with this stress, the organisms may undergo metabolic alterations and energetic trade-offs [28]. Isocitrate dehydrogenase-IDH (aerobic pathways) and lactate dehydrogenase-LDH (anaerobic pathways), are useful biomarkers for addressing alterations in the energy metabolism [29-31]. Cellular oxygen consumption rate can be measured through the electron transport system (ETS) activity, as energetic status information [32]. Furthermore, acetylcholinesterase (AChE), an enzyme that hydrolyses the neurotransmitter acetylcholine, is a relevant biomarker in the identification of neuromuscular toxic affects of a xenobiotic [14,33].

By addressing these multi-biological levels of biological organisation-ranging from survival to behavioural changes such as feed intake and motricity, and biochemical endpoints - the present study contribute to the knowledge on the sulfoxaflor mode of 
toxic action and impact on this non-targeted aquatic crustacean and provide insight into potential impacts and higher levels of biological organisation.

\section{Materials and Methods}

\subsection{Ethical Experiments}

Although not mandatory for invertebrates and considering the welfare of the animals used for experimental and scientific purposes, all experiments were conducted according to the European Union Council's (Directive 2010/63/EU) [34] ethical guidelines and the Portuguese Ministry of agriculture, sea, environment and territory planning (Decreto-Lei 113/2013) [35].

\subsection{Crab Sampling and Acclimation}

Carcinus maenas adult males were collected in Óbidos lagoon, Portugal, in fishermen traps (net mesh of $20 \mathrm{~mm}$ ). The organisms were transported in dry containers to aquaculture facilities in CETEMARES building, Peniche, for further acclimation and experimental procedures.

Size-selected green crabs, for acute and sub-lethal tests, had an average carapace length of $3.44 \pm 0.18 / 3.63 \pm 0.27 \mathrm{~cm}$ (mean $\pm \mathrm{SD}$ ), and wet weight of $9.29 \pm 1.45 / 10.75 \pm 2.34 \mathrm{~g}$ (mean $\pm \mathrm{SD}$ ), respectively. These were re-immersed in containers filled with natural filtered seawater to release ammonia [36], and to remove sediment, algae, or other detritus attached to their body, and then transferred into a recirculating aquaculture system (RAS). This RAS contained mechanical (50 $\mu \mathrm{m}$ glass fibre bags, TMC) and biological filtration (bioballs with nitrifying bacteria), along with chemical UV disinfection ( $\mathrm{V}^{2}$ Vecton $\left.300, \mathrm{TMC}\right)$. Acclimation took place for a period of at least 14 days with a photoperiod set to $16 \mathrm{~h}$ light and $8 \mathrm{~h}$ dark [37], and water parameters were set as found in the Óbidos lagoon during spring: the temperature was set to $19^{\circ} \mathrm{C}$, seawater salinity between 32 and $34 \mathrm{ppt}, \mathrm{pH}$ maintained at 7.9 to 8.2 , and dissolved oxygen (DO) at 6 to $8 \mathrm{mg} \mathrm{L}^{-1}$ [38]. These parameters were evaluated daily with a multiparameter probe (YSI, Professional Plus, Yellow Springs, $\mathrm{OH}$, USA). Crabs were fed every other day with mussel kernels (Mytilus edulis). To maintain quality, water was syphoned the day after feeding, and partial water changes $(30 \%$ or $60 \%$ ) were performed. Organisms were not fed $24 \mathrm{~h}$ before the experiments, as advised in Rodrigues et al. [39].

\subsection{Experimental Design}

\subsubsection{Material and Pesticide Stock Solution}

Before experimental bioassays, glass materials followed a washing scheme of nitric acid bath $\left(\mathrm{HNO}_{3} 10 \%\right)$ for $24 \mathrm{~h}$, Extran base bath $(10 \%)$ another $24 \mathrm{~h}$, and then machine wash (acid, basic, and distilled water finish), to ensure clean material.

Closer $^{\circledR}$, Isoclast ${ }^{\mathrm{TM}}$ active (Dow AgroSciences, Sevilla, Spain), suspension concentrate containing $120 \mathrm{~g} \mathrm{~L}^{-1}$ or $11.3 \%(w / w)$ of sulfoxaflor (CAS number 946578-00-3, Dow AgroSciences, 2014 [8]), was stored at room temperature protected from light. The sulfoxaflor stock solution $\left(0.6 \mathrm{mg} \mathrm{mL}^{-1}\right.$ nominal concentration) was prepared with ultrapure water (MilliQ ${ }^{\circledR}$, Merck, Darmstadt, Germany, HE, DE).

\subsubsection{Acute Toxicity Test}

To estimate lethal concentrations, six C. maenas, per treatment, were exposed for $96 \mathrm{~h}$ to the pesticide sulfoxaflor to one of the six nominal concentrations determined through logarithmic calculations $\left(0,1.0,1.6,2.5,4.0,6.3\right.$, or $10 \mathrm{mg} \mathrm{L}^{-1}$ in seawater).

Green crabs were randomly exposed in individual glass flasks containing $700 \mathrm{~mL}$ of the exposure solution at the desired final concentration and constant aeration. Exposure solution was renewed daily. Seawater parameters were set as described above for acclimation (see Section 2.2) and verified and adjusted daily after using a multiparameter probe (YSI, Professional Plus, Yellow Springs, OH, USA) (Table S1). 


\subsubsection{Sub-Lethal Toxicity Tests}

Fifteen C. maenas, per treatment, were exposed to sulfoxaflor for $168 \mathrm{~h}$ ( 7 days) to one of the seven treatments determined by logarithmic calculations $(0,0.05,0.08,0.15,0.27,0.5$, or $\left.0.9 \mathrm{mg} \mathrm{L}^{-1}\right)$. The nominal concentration range for these tests was defined according to the estimated $\mathrm{LC}_{10}$ from the acute exposure [1.74 $\mathrm{mg} \mathrm{L}^{-1}$ ( $\pm 95 \% \mathrm{CI}$ : 0.82-2.30)], encompassing half the $\mathrm{LC}_{10}$ (approx.) as the higher concentration in order to minimize lethal effects.

The organisms were exposed in individual glass flasks filled with saltwater plus the necessary volume of the pesticide stock solution to meet target concentrations to $700 \mathrm{~mL}$. Replicates were randomly distributed and provided with constant aeration. Exposure solution was renewed daily. Saltwater parameters were set as described above for acclimation (see Section 2.2), and verified daily using a multiparameter probe (YSI, Professional Plus, Yellow Springs, OH, USA) (Table S1). Organisms were fed ad libitum on days 3 and 6 with mussel kernels (Mytilus edulis).

On day 3 of exposure, seven replicates of each treatment were ice anaesthetised $\left(-20^{\circ} \mathrm{C}\right.$ for $\left.15 \mathrm{~min}\right)$, then euthanized by using a needle to perforate both hind nerve centre and front nerve centre [40] and dissected. Hepatopancreas (H), gills (G), and muscle (M) from the abdomen were collected for biochemical analysis. Tissues were stored at $-80^{\circ} \mathrm{C}$ prior to homogenization and further analysis.

Behavioural tests, namely feed intake and motricity, were carried out in the remaining replicates on day 3 and on day 6 of exposure, with a minimum of seven replicates per treatment (maximum $N=8$ ). The experiment was performed at day 6 in order for the minor manipulation not to interfere with the endpoints addressed at day 7. Prior to testing, crabs' wet weight and carapace length were assessed to normalize for food intake values. A motricity evaluation method was created and optimized, based on the forage activity [41] and the competition between Carcinus maenas and Hemigrapsus takanoi for food [42]. Briefly, the motricity test was performed by placing mussel kernels in the same point of the exposure containers, and then, the time taken by the crab to react and reach the food was counted, establishing $5 \mathrm{~min}$ as the time limit. For the feed intake, initial mussel kernels wet weight was measured, prior to the motricity test, and the organisms were fed for a $4 \mathrm{~h}$ period, after which the food final wet weight was measured for feed consumption quantification, adapted from Abreu at al. [43].

On day 7 of exposure, the remaining organisms (minimum of seven) were ice anaesthetised, euthanized and the tissues dissected for biochemical analysis.

\subsection{Tissue Preparation and Biomarkers Analysis}

Carcinus maenas tissues were homogenized in $0.1 \mathrm{M}$ potassium-phosphate $\left(\mathrm{K}_{2} \mathrm{HPO}_{4} /\right.$ $\mathrm{KH}_{2} \mathrm{PO}_{4}$ ) buffer ( $\mathrm{pH} 7.4$ ) in a proportion (m:v) of 1:5 (muscle and gills) and 1:15 (hepatopancreas), using a mechanical homogenizer (Ystral, X10/25, Ballrechten-dottingen, BW, DE).

Biomarker responses after 3 and 7 days of exposure were addressed. Muscle homogenates were centrifuged at $3000 \times g$ during $5 \mathrm{~min}$ at $4{ }^{\circ} \mathrm{C}$ and the supernatant separated into different microtubes for protein quantification and the activity determination of isocitrate dehydrogenase (IDH), lactate dehydrogenase (LDH) and acetylcholinesterase (AChE). Additionally, muscle homogenates plus ETS buffer [0.1 M Tris-HCl, $15 \%(w / v)$ Poly Vinyl Pyrrolidone, $153 \mu \mathrm{M} \mathrm{MgSO}_{4}, 0.2 \%(w / v)$ Triton X-100, and $\mathrm{pH}$ 8.5] were centrifuged at $1000 \times g$ for $10 \mathrm{~min}$ at $4{ }^{\circ} \mathrm{C}$ and the supernatant separated for electron transport system (ETS) analysis. Two extra aliquots of muscle homogenate were separated for lipid peroxidation [LPO; in 4\% BHT (2,6-Di-tert-butyl-4-methylphenol) in methanol] and DNA damage (DNAd) measurements. Hepatopancreas homogenates were centrifuged at $10,000 \times g$ for $20 \mathrm{~min}$ at $4{ }^{\circ} \mathrm{C}$ and the post-mitochondrial supernatant (PMS) distributed into microtubes to measure protein content and the activity of superoxide dismutase (SOD) and glutathione S-transferase (GST). Hepatopancreas homogenates were also separated for LPO and DNAd quantification. Gill homogenates were used for quantification of reactive oxygen species (ROS), LPO, and DNAd. All homogenates and separated aliquots were stored at $-80{ }^{\circ} \mathrm{C}$ 
until further analysis. Spectrophotometric measurements were performed in triplicates using a Synergy H1 Hybrid Multi-Mode microplate reader (Biotek ${ }^{\circledR}$ Instruments, Winooski, VT, USA) and using a homogenization buffer as reaction blanks.

\subsubsection{Protein Quantification}

Protein quantification was performed for normalization purposes following the Bradford method [44] and adapted to a 96-well microplate, using bovine y-globulin (SigmaAldrich, Darmstadt, Germany, HE, DE) as protein standard solution. Absorbance was read at $600 \mathrm{~nm}$. The results were represented in $\mathrm{mg}$ of protein $\mathrm{mL}^{-1}$.

\subsubsection{Energy Metabolism Related Biomarkers}

Isocitrate dehydrogenase (IDH) activity was quantified following the Ellis and Goldberg [45] method and adapted to a microplate [30]. IDH, an enzyme involved with aerobic metabolism, plays a role in the decarboxylation of isocitrate (DL-isocitric acid). Consequently, the production of NADPH during this process was followed at $330 \mathrm{~nm}$ for $3 \mathrm{~min}$ (min). Results were expressed as nmol min ${ }^{-1} \mathrm{mg}^{-1}$ of protein $\left(\varepsilon=6.22 \times 10^{3} \mathrm{M}^{-1} \mathrm{~cm}^{-1}\right)$. Lactate dehydrogenase (LDH) activity was assessed following the methods of Vassault [46] and Diamantino et al. [29]. LDH, an enzyme involved with anaerobic metabolism, converts pyruvate to lactate through oxidation of $\mathrm{NADH}$ into $\mathrm{NAD}^{+}$. NADH decrease is followed at $330 \mathrm{~nm}$ for $3 \mathrm{~min}$. Results were expressed in nmol min ${ }^{-1} \mathrm{mg}^{-1}$ of protein $\left(\varepsilon=6.22 \times 10^{3} \mathrm{M}^{-1} \mathrm{~cm}^{-1}\right)$. The electron transport system (ETS) activity biomarker consists of the determination of the oxygen consumption rate, through the method described by De Coen and Janssen [32], and following the built-up of the complex INT (p iodo-nitrotetrazolium)-formazan for $3 \mathrm{~min}$ at $490 \mathrm{~nm}$. Then, a stoichiometrical relationship ( $2 \mu \mathrm{mol}$ of INT-formazan formed is equivalent to $1 \mu \mathrm{mol}$ of oxygen consumed) was applied to determine the oxygen consumption rate. Results were presented in $\mathrm{nmol}_{2} \mathrm{~h}^{-1} \mathrm{~g}^{-1}$ of wet weight.

\subsubsection{Detoxification and Oxidative Stress Related Biomarkers}

Glutathione S-transferase (GST) activity was quantified based in Habig et al. [47] method. The compound thioether is produced by the conjugation between the substrate 1-chloro-2,4-dinitrobenzene (CDNB) and reduced glutathione (GSH) in the presence of GST. The thioether formation is followed by reading the absorbance at $330 \mathrm{~nm}$ for $3 \mathrm{~min}$. Results were expressed as nmol min ${ }^{-1} \mathrm{mg}^{-1}$ protein $\left(\varepsilon=9.6 \times 10^{3} \mathrm{M}^{-1} \mathrm{~cm}^{-1}\right)$. Reactive oxygen species (ROS) levels were quantified according to Socci et al. [48] method by measuring the conversion of non-fluorescent $2^{\prime}, 7^{\prime}$-dichlorofluorescein diacetate (DCFDA) into $2^{\prime}, 7^{\prime}$-dichlorofluorescein (DCF) in the presence of ROS. DCF is a highly fluorescent compound read at 485:525 nm excitation: emission. Results were expressed in $\mathrm{FU} \mathrm{mg}^{-1}$ of wet weight. Superoxide dismutase (SOD) activity quantification followed the McCord and Fridovich [49] method, adapted to microplate [30]. The protocol consists of measuring the inhibition of the reduction of cytochrome $\mathrm{C}$, resulting from the competition of SOD for the superoxide radicals $\left(\mathrm{O}_{2}{ }^{-}\right)$produced by the xanthine/xanthine oxidase complex. The reduction of cytochrome $\mathrm{C}$ was observed at $550 \mathrm{~nm}$ for $10 \mathrm{~min}$. Results were expressed as $\mathrm{U} \mathrm{mg}^{-1}$ of protein. Lipid peroxidation (LPO) was measured following the methods described by Bird and Draper [50] and Ohkawa et al. [51], adjusted from Torres et al. [52]. The samples were submitted to a sequence of treatments with trichloroacetic acid (TCA), Tris- $\mathrm{HCl}$ with DTPA, and 2-thiobarbituric acid (TBA). Following heat and centrifugation, the supernatant was used to quantify the content of thiobarbituric acid reactive substances (TBARS) at $535 \mathrm{~nm}$. Results were expressed as nmol TBARS $\mathrm{g}^{-1}$ of wet weight $\left(\varepsilon=1.56 \times 10^{5} \mathrm{M}^{-1} \mathrm{~cm}^{-1}\right)$. DNA damage (DNAd) was determined following the DNA alkaline precipitation assay [53], adapted from De Lafontaine et al. [54]. The protocol consists of centrifuging samples to obtain the precipitation of intact DNA associated with nucleoproteins. The supernatant, containing damaged DNA (strand breaks), was mixed 
with Hoechst dye ( $1 \mu \mathrm{g} \mathrm{mL}^{-1}$ bis-benzimide, Sigma-Aldrich) and the fluorescence read at 360:460 $\mathrm{nm}$ of excitation:emission. Results were expressed as $\mu \mathrm{g} \mathrm{g}^{-1}$ of wet weight.

\subsubsection{Neuromuscular Toxicity}

Acetylcholinesterase (AChE) activity was measured following the Ellman et al. [55] method, adapted to a microplate [56]. AChE plays a role in catalysing the hydrolysis of acetylthiocholine, producing acetate and thiocholine. DTNB [5,5'-dithiobis-(2-nitrobenzoic acid] reacts with thiocholine, generating the yellow 2-nitro-5-thiobenzoate anion $\left(\mathrm{TNB}^{2-}\right)$. This reaction was read at $414 \mathrm{~nm}$ for $5 \mathrm{~min}$. Results were expressed in $\mathrm{nmol} \mathrm{min}{ }^{-1} \mathrm{mg}^{-1}$ of protein $\left(\varepsilon=13.6 \times 10^{3} \mathrm{M}^{-1} \mathrm{~cm}^{-1}\right)$.

\subsection{Statistical Analysis}

For acute toxicity, the estimation of lethal concentrations (LCx) was performed through probit analysis. All data were checked for normality using the Shapiro-Wilk normality test $(p>0.05)$ and for homoscedasticity using Levene's test $(p>0.05)$. The data was analysed through generalized linear modelling (GzLM, $p<0.05)$, where biomarker and behavioural responses were used as response variables, while concentration and exposure times were used as predictable factors. After the GzLM, pairwise comparisons were performed by Least Significant Difference analysis (LSD, $p<0.05$ ), and model validation was carried out as in [57-59]. Significant positive or negative correlations between biomarkers and behavioural responses were assessed through Spearman correlations $(* p$-value $<0.05$, ** $p$-value $<0.01)$. For the mentioned data analysis, IBM SPSS Statistic 26 software was used. Furthermore, the principal component analysis (PCA) was employed to investigate associations between biomarkers/behavioural endpoints and pesticide concentrations. Detrended correspondence analysis (DCA) was applied to determine if the lengths of gradient were $<3$ on the first axis, referring to linear model. PCAs were then performed on averaged biomarkers and behavioural data. DCA and PCA analyses were performed with the software CANOCO version 4.5 for windows (Biometris, Wageningen, GE, NL) [60].

\section{Results}

The estimated $96 \mathrm{~h} \mathrm{LC}_{50}( \pm 95 \% \mathrm{CI})$ for sulfoxaflor was $2.88 \mathrm{mg} \mathrm{L}^{-1}(2.14-4.00)$ and the $96 \mathrm{~h} \mathrm{LC}_{10}$ was $1.74 \mathrm{mg} \mathrm{L}^{-1}(0.82-2.30)$. Other LCx values are presented in Table S2.

\subsection{Behavioural Effects}

Behavioural changes were not found to be significant after 3 days of exposure $(p>0.05)$. However, sulfoxaflor significantly affected the behavioural responses after 6 days of exposure, decreasing the feed intake 39.5 and $44.9 \%$, at the two highest concentrations tested, $0.5(p=0.008)$ and $0.9 \mathrm{mg} \mathrm{L}^{-1}(p=0.020)$, respectively (Figure $\left.1 \mathrm{a}\right)$, and increasing the time taken to reach the food (motricity) at the highest concentration $(p<0.001$; Figure 1b).

\subsection{Biochemical Biomarkers}

The results are here divided into each analysed tissue: gills and hepatopancreas (detoxification-GST, and oxidative stress-SOD, ROS, LPO, DNAd; Figures 2 and S1), and muscle (oxidative stress-LPO, DNAd, energy metabolism-LDH, IDH, LDH/IDH ratio, ETS, and neuromuscular toxicity related-AChE; Figure 3). In the gills, no significant effects were found in reactive oxygen species (ROS) levels after three days of exposure (T3) $(p>0.05)$. However, there was a significant decrease in ROS at a concentration of $0.08 \mathrm{mg} \mathrm{L}^{-1}$ after 7 days of exposure (T7; $p=0.004$, Figure 2a). Lipid peroxidation (LPO) from gills presented a significant reduction at the highest concentration in T3 $(p=0.006$, Figure 2b). LPO quantified in hepatopancreas has increased at $0.05 \mathrm{mg} \mathrm{L}^{-1}$ and again at concentrations of $0.27 \mathrm{mg} \mathrm{L}^{-1}$ and higher but only in T7 ( $p<0.05$, Figure 2c). 
a)

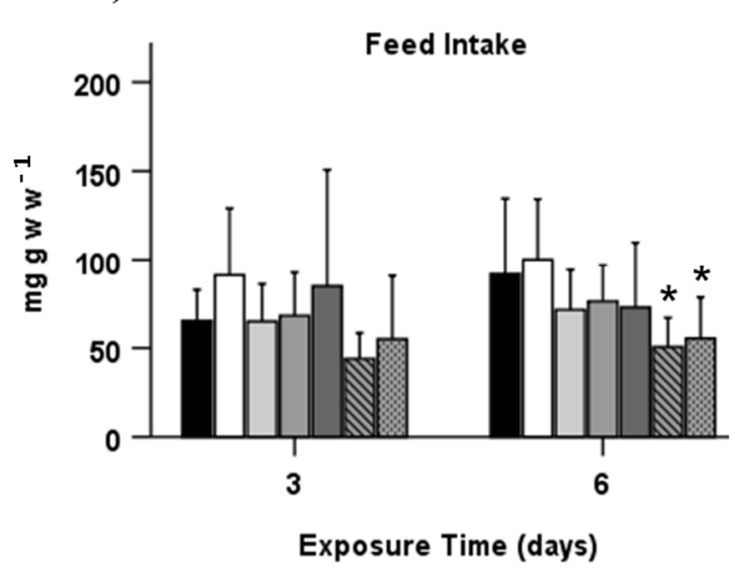

b)

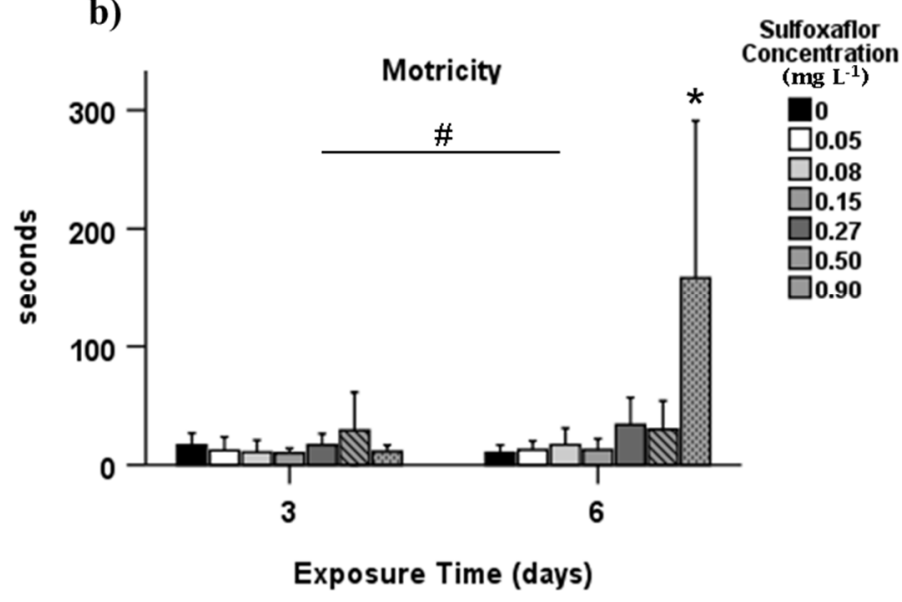

Figure 1. Behavioural responses of Carcinus maenas after 3 and 6 days of exposure to sulfoxaflor (mean \pm SD): (a) feed intake; (b) motricity. * Indicates statistically significant differences in relation to control, and \# denotes statistically significant differences between exposure time 3 and 6 ( $p<0.05$, GzLM, followed by the pairwise comparison method with adjustment to LSD).

a)

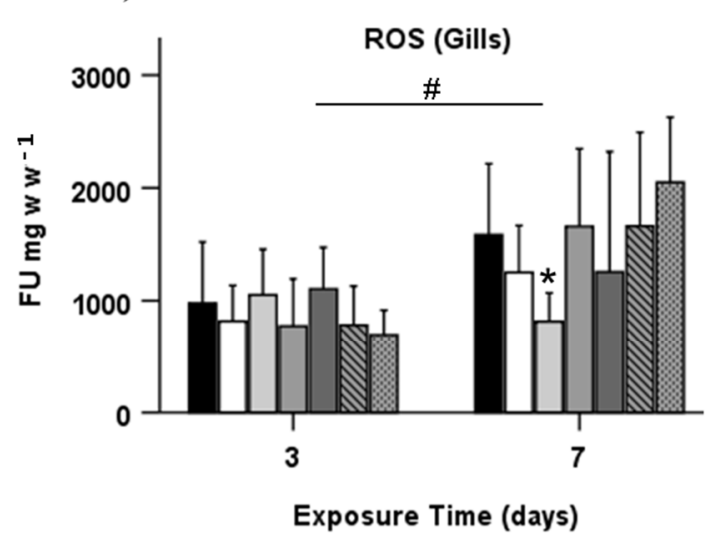

b)

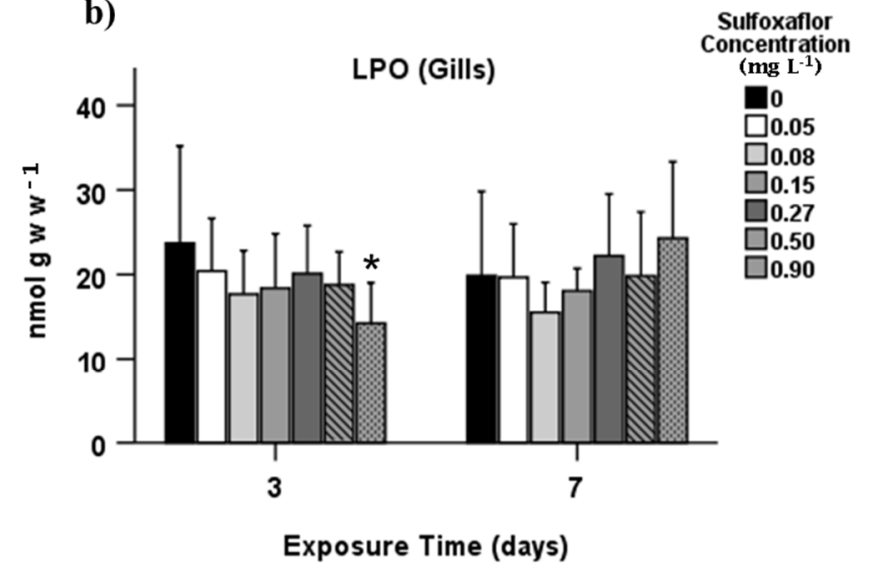

c)

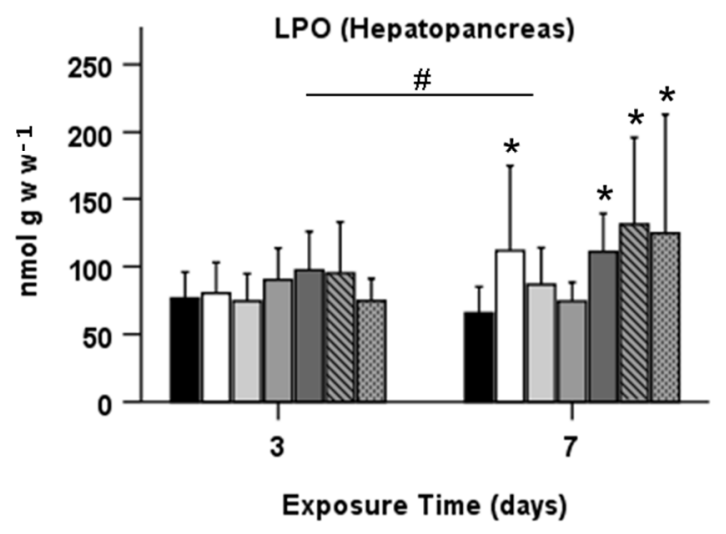

Figure 2. Biochemical biomarkers responses measured in gills and hepatopancreas of Carcinus maenas after 3 and 7 days of exposure to sulfoxaflor (mean $\pm \mathrm{SD}$ ), related to oxidative stress: (a) reactive oxygen species (ROS); (b) lipid peroxidation (LPO) measured in gills; and (c) LPO measured in hepatopancreas. * Indicates statistically significant differences in relation to control, and \# denotes statistically significant differences between exposure time 3 and $7(p<0.05$, GzLM, followed by pairwise comparison method with adjustment to LSD). Only the biomarkers with significant differences are shown. 

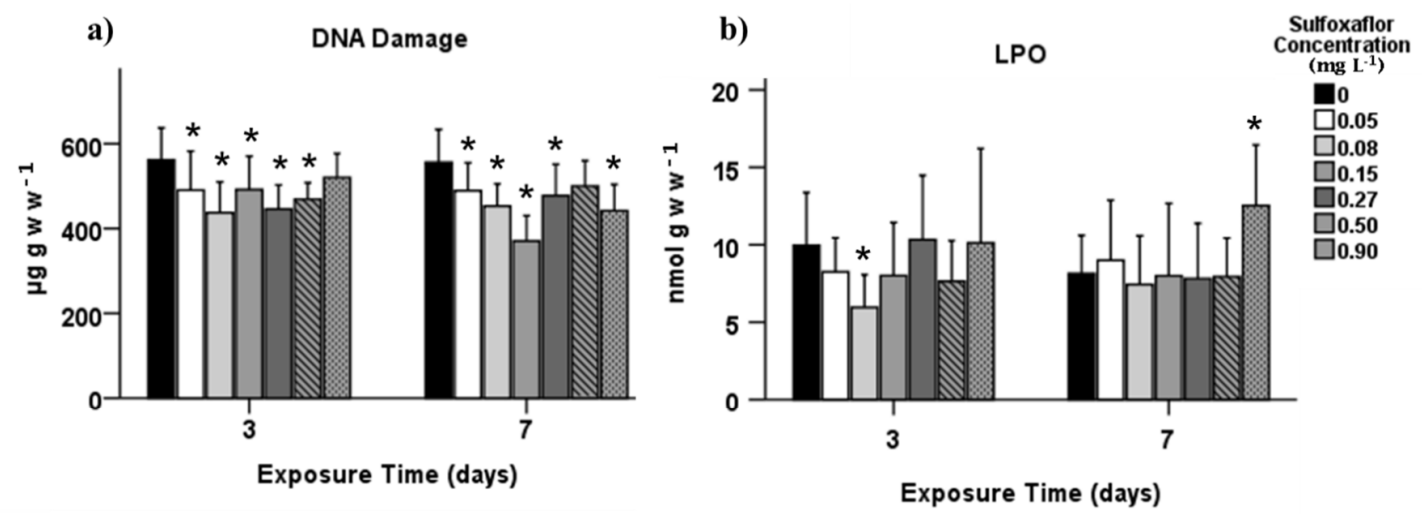

c)

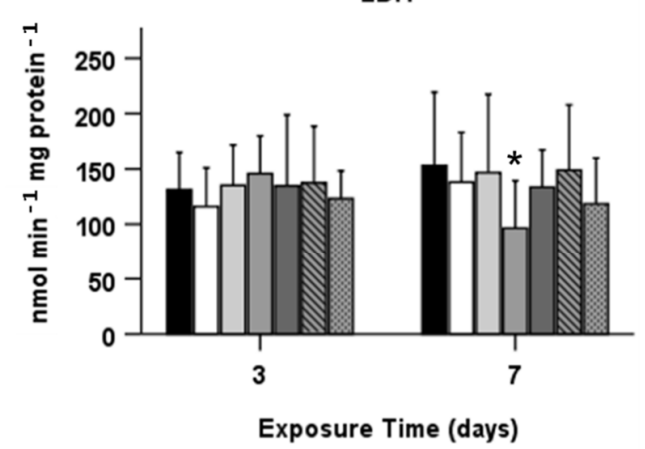

e)

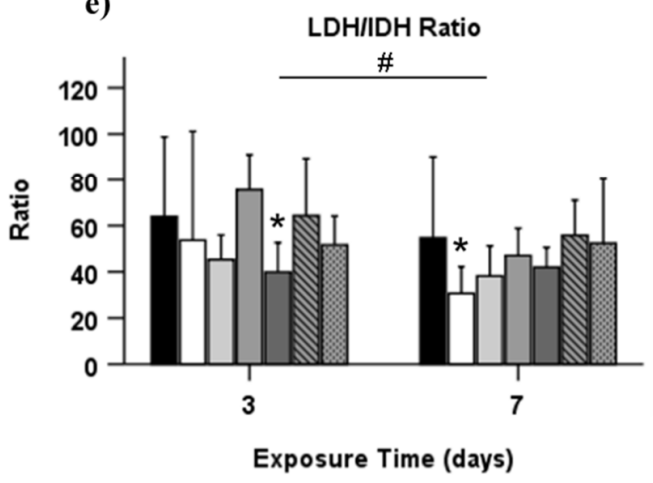

d)
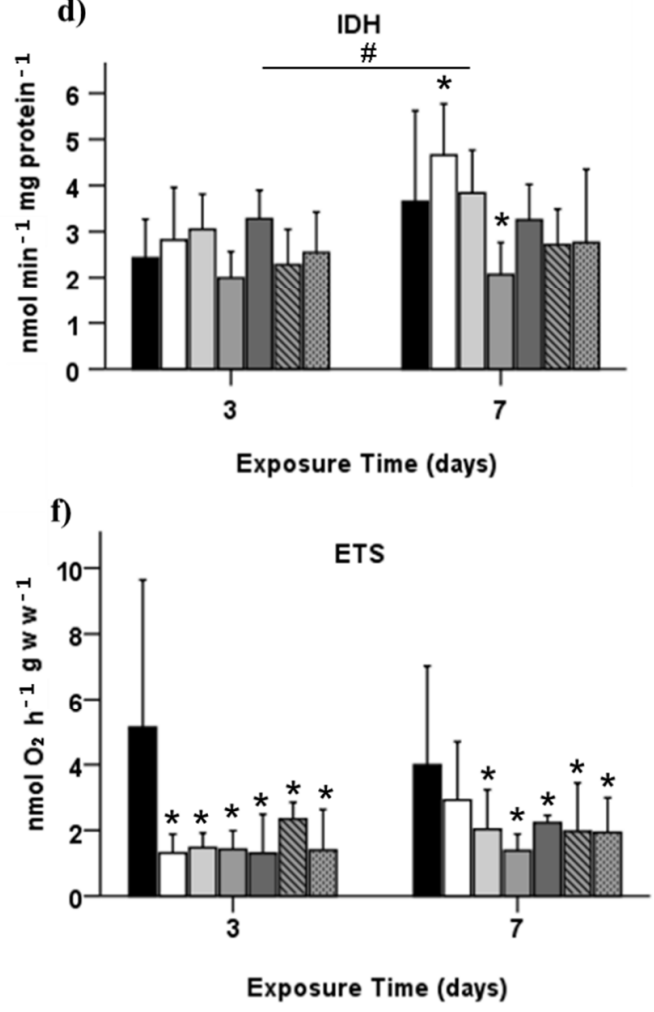

g)

AChE

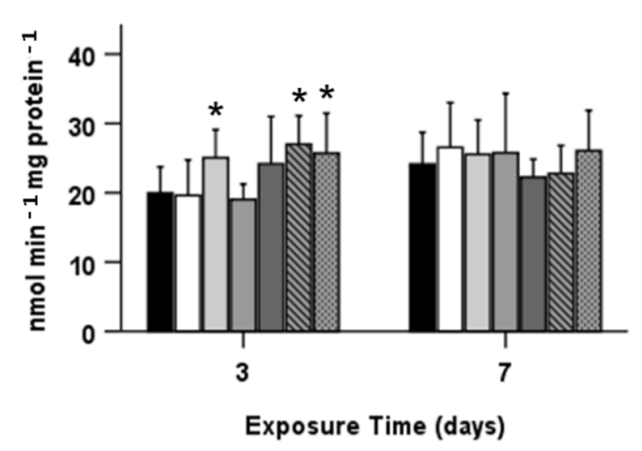

Figure 3. Biochemical biomarkers responses measured in muscle of Carcinus maenas after 3 and 7 days of exposure to sulfoxaflor (mean $\pm \mathrm{SD}$ ), related to oxidative stress-(a) DNA damage; (b) lipid peroxidation (LPO), energy metabolism(c) lactate dehydrogenase (LDH); (d) isocitrate dehydrogenase (IDH); (e) LDH/IDH ratio; (f) electron transport system (ETS), and neuromuscular toxicity-(g) acetylcholinesterase (AChE). * Indicates statistically significant differences in relation to control, and \# denotes statistically significant differences between exposure time 3 and 7 ( $p<0.05$, GzLM, followed by pairwise comparison method with adjustment to LSD). Only the biomarkers with significant differences are shown. 
The phase II biotransformation enzyme, GST, and the antioxidant enzyme, SOD, assessed in hepatopancreas were not affected ( $p>0.05$; Figure S1a,b, respectively). Furthermore, no effect was found concerning DNA damage (DNAd) analysed in the hepatopancreas and gills ( $p>0.05$; Figure S1c,d, respectively).

Concerning oxidative stress assessed in muscle, DNAd was significantly reduced in almost all concentrations from both T3 and T7 ( $p<0.05$; Figure 3a), and LPO from muscle had a significant increase in 77 at $0.9 \mathrm{mg} \mathrm{L}^{-1}(p=0.011$, Figure $3 b)$.

The energy metabolism of the green crabs was affected after exposure to sulfoxaflor. The anaerobic and aerobic metabolism was significantly affected in T7 with a LDH decrease at $0.15 \mathrm{mg} \mathrm{L}^{-1}$, and an IDH increase at $0.05 \mathrm{mg} \mathrm{L}^{-1}$ and a decrease at $0.15 \mathrm{mg} \mathrm{L}^{-1}$ ( $p<0.05$, Figure $3 c, d$, respectively). The $\mathrm{LDH} / \mathrm{IDH}$ ratio showed a significant reduction at $0.27 \mathrm{mg} \mathrm{L}^{-1}$ in T3 and $0.05 \mathrm{mg} \mathrm{L}^{-1}$ in T7 ( $p=0.038 ; p=0.026$, respectively; Figure 3e), as well as a significant difference between exposure time, with a decrease in T7 $(p=0.016)$. Electron transport system (ETS) activity was significantly reduced in all concentrations from both exposure times ( $p<0.05$, Figure 3f), except for the lower concentration in T7.

Sulfoxaflor significantly increased the AChE activity at concentrations $0.08,0.5$ and $0.9 \mathrm{mg} \mathrm{L}^{-1}$ in T3 ( $p=0.048, p=0.006$ and $p=0.026$, respectively). No differences were found in T7 ( $p>0.05$, Figure $3 g)$.

\subsection{Integrative Analysis of Behavioural and Biochemical Responses}

To integrate all the responses, two principal component analyses (PCA) were performed, one for exposure time T3 (Figure 4a) and another for exposure time T7 (Figure 4b). For the T3 PCA, the endpoints that contributed the most to explain concentration variability (diamonds) were LPO (G), GST (H), DNAd (M), ETS (M), and AChE (M). LPO (G) was also significantly positively correlated with ROS $(\mathrm{G})$, as could be verified by Spearman's correlations $(p<0.001, r=0.517$; Table S3), meaning that those variables increase or decrease simultaneously with sulfoxaflor exposure. Behavioural responses had minimum contribution in T3 (Figure 4a), with no correlations between them (Spearman, $p>0.05$ ), while their influence increased in T7 (Figure $4 \mathrm{~b}$ ), mainly due to motricity, which at this point is negatively correlated with feed intake ( $p=0.026, \mathrm{r}=-0.318$; Table S3). In fact, in the T7 PCA, motricity is associated with several endpoints, being the positive association with LPO (M) significantly correlated (Spearman, $p=0.023, r=0.324$, Table S3). As in T3, the positive correlation between ROS $(\mathrm{G})$ and LPO $(\mathrm{G})$ continues to be verified at T7 $(p<0.001$, $r=0.562$ ). Moreover, in T7 PCA, it is possible to observe a clear separation along PC1 axis between the lowest and the highest concentrations. The three highest concentrations are mainly characterized by lower detoxification capacity (GST), higher LPO levels, and effects on behaviour (higher motricity and lower feed intake). 
a)
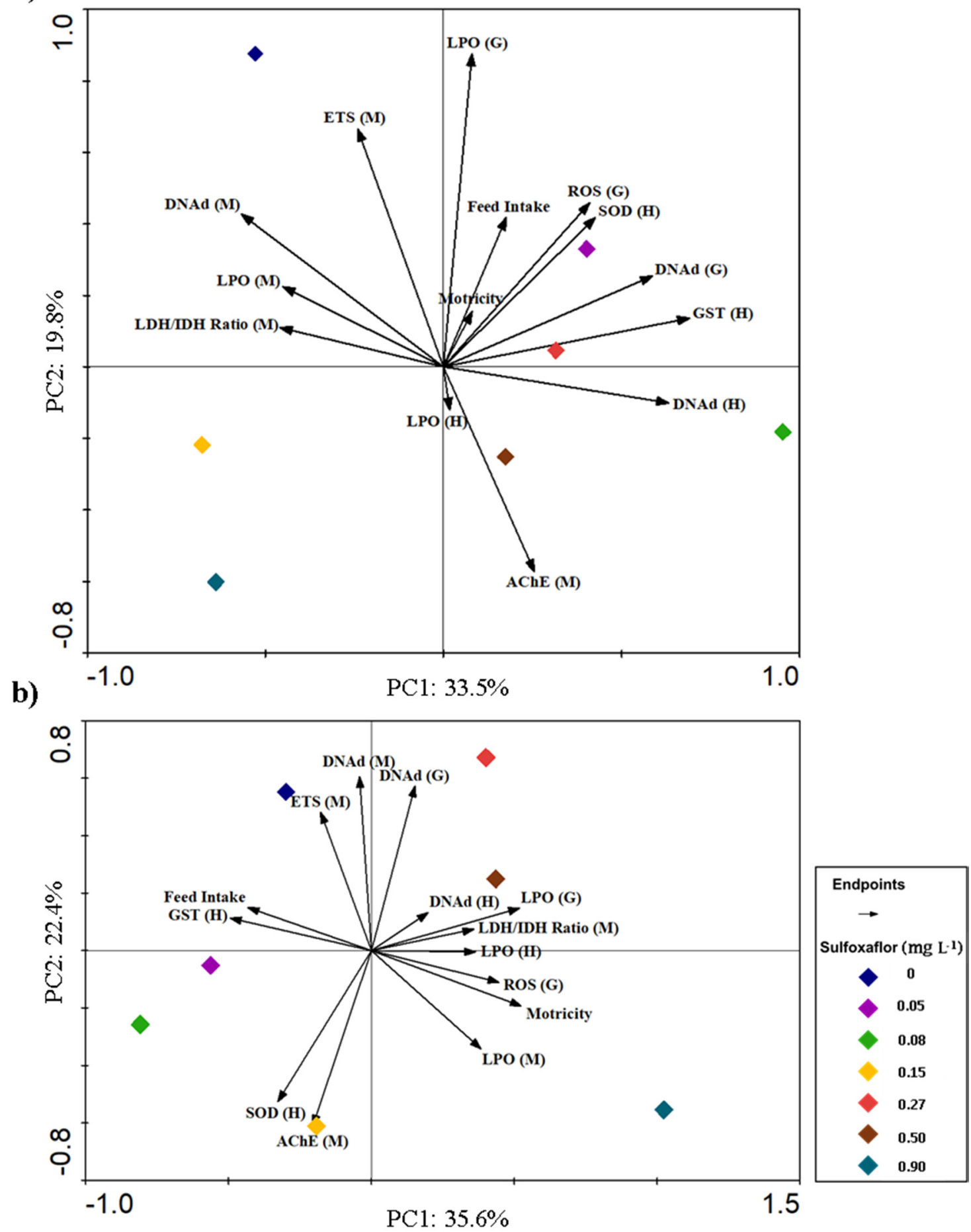

Figure 4. Principal component analysis (PCA) of biochemical/behavioural data average and sulfoxaflor concentrations on different times of exposure: (a) exposure time 3 days; (b) exposure time 7 days. Diamonds represent different sulfoxaflor concentrations applied in sub-lethal assays, and arrows indicate all types of behavioural responses (feed intake and motricity) and biomarkers assessed. From gills: ROS = reactive oxygen species; DNAd (G) = DNA damage; LPO $(\mathrm{G})=$ lipid peroxidation. From hepatopancreas: GST = glutathione S-transferase; SOD = superoxide dismutase; DNAd $(\mathrm{H})=$ DNA damage; LPO $(\mathrm{H})=$ lipid peroxidation. From muscle: $\mathrm{LDH} / \mathrm{IDH}$ ratio = lactate dehydrogenase/isocitrate dehydrogenase ratio; ETS = electron transport system; DNAd $(\mathrm{M})=$ DNA damage; LPO $(\mathrm{M})=$ lipid peroxidation; $\mathrm{AChE}=$ acetylcholinesterase. 


\section{Discussion}

Neonicotinoids reported mode of action (MoA) occurs by affecting the nervous system through a continuous stimulation, as a result of the interaction of these chemicals with the nicotinic acetylcholine receptors (nAChR) [61]. Studies have demonstrated that neonicotinoids can affect, directly or indirectly, non-target organisms, such as fish, birds, mammals [62], and also aquatic invertebrates [61]. In this context, the bumblebee Bombus terrestris exposed to sulfoxaflor revealed sub-lethal adverse effects, by producing less workers and consequently producing fewer reproductive offspring [12] and leading to reduced egg laying [63]. Additionally, according to the technical bulletin of Dow AgroSciences [8] and Niesen et al. [64], sheepshead minnows (Cyprinodon variegatus) had reduced growth when exposed to sulfoxaflor. Furthermore, this insecticide is considered highly toxic to mysid shrimp (Americamysis bahia) [64], and recent studies have demonstrated sulfoxaflor toxicity to the zebrafish Danio rerio $[65,66]$. Still, few studies have demonstrated sulfoxaflor effects on non-target estuarine/marine organisms.

The current study investigated acute and sub-lethal toxicity on adult male Carcinus maenas exposed to sulfoxaflor, demonstrating distinct effects on different levels of biological organisation. A $96 \mathrm{~h} \mathrm{LC}_{50}$ of $35.13 \mathrm{mg} \mathrm{L}^{-1}$ and of $266 \mathrm{mg} \mathrm{L}^{-1}$ were found for the fish Danio rerio and Cyprinodon variegatus, respectively $[64,66]$, while for crustaceans a $96 \mathrm{~h} \mathrm{LC}_{50}$ of $0.64 \mathrm{mg} \mathrm{L}^{-1}$ was found for Americamysis bahia [64] and $2.88 \mathrm{mg} \mathrm{L}^{-1}$ for C. maenas (present study). These latter lower $\mathrm{LC}_{50}$ suggest that sulfoxaflor presents higher acute toxicity to marine crustaceans than freshwater/marine fish.

Carcinus maenas exposure to sulfoxaflor resulted in a prolonged time to reach the food and a lower feed intake. Food consumption rate has been used to evaluate $C$. maenas behaviour after exposure to contaminants $[43,67]$. Sulfoxaflor acts in the nervous system of organisms through interaction with $\mathrm{nAChR}$ and this MoA may be responsible for the behavioural detrimental responses in C. maenas, similar to those observed in the aphid Myzus persicae related to excitatory symptoms induced by sulfoxaflor [4,11]. A negative correlation between feed intake and motricity (T6) was obtained in spearman correlation and observed in PCA analysis, meaning that with increasing concentrations of sulfoxaflor, there is a tendency for longer time to reach food and for a lower food intake, showing a pronounced behavioural impact, which can alter their fitness and chances of survival in natural ecosystems [68].

Previous studies have reported that the neurotransmission enzyme acetylcholinesterase (AChE) is the main cholinesterase form available in C. maenas muscle, as seen in Rodrigues et al. [69]. A recent publication has demonstrated that sulfoxaflor affected AChE in Danio rerio [66], increasing its activity in brain and muscle tissues, despite not presenting a dose-dependent response. In the present study, C. maenas exposed to sulfoxaflor also demonstrated a significant increase in $\mathrm{AChE}$ after 3 days of exposure (T3) and presented no significant responses after 7 days of exposure (T7). Several studies reported AChE activity increase after exposure to different contaminants, e.g., Reddy and Venugopal [70], Silva et al. [71], and Qi et al. [72]. The increased AChE activity, after exposure to sulfoxaflor, may be related to sulfoxaflor's binding to the receptor acting as an agonist chemical, causing excitatory responses to the organisms. It is expected that sulfoxaflor competes with acetylcholine for the $\mathrm{nAChR}$ receptor [73]. Thus, it is reasonable that in the range of concentrations applied in this study, the organisms might be accumulating $\mathrm{AChE}$ in the synaptic cleft due to increased and continuous agonist-based neuromuscular stimuli and to ACh accumulation in this cleft.

Regular cellular functions commonly produce ROS, while xenobiotics can potentiate its production and induce toxicity in aquatic organisms, as reviewed in Livingstone [74]. According to previous studies, neonicotinoids have demonstrated an imbalance in the antioxidant system in aquatic organisms, and induce oxidative damage correlated with a high production of ROS [75-77]. A set of defence mechanisms can be activated to remove these oxyradicals, such as antioxidant enzymes and low molecular weight scavengers [22], thus avoiding oxidative damage in the organisms [21]. SOD and GST are some of the 
enzymes involved in the process of defence against oxyradicals and in detoxification mechanisms [26,27]. Despite no significant responses on these enzymes' activities were found upon exposure to sulfoxaflor, in the T7 PCA for the higher concentrations, the decrease of GST relates to increasing LPO levels. The GST failure to detoxify, and even the inability of SOD to remove ROS, may lead to an increase in LPO levels at the highest concentration. Benli and Çelik [65] found that sulfoxaflor significantly reduced GST activity in Danio rerio gills after $96 \mathrm{~h}$ of exposure at concentrations 1.75 and $3.51 \mathrm{mg} \mathrm{L}^{-1}$.

Besides these enzymatic observations, a significant reduction of oxidative damage was detected in LPO $(\mathrm{G})$ and DNAd (M), mainly in T3 exposure time. Given this, one cannot exclude that other antioxidant and/or detoxification enzymes not addressed in this study may be activated as a fast response to the initial stage of exposure and induce an overcompensation in the first instance. However, these lower damage effects are most probably derived from lower activity and, consequently, lower respiration rates, thus reducing their metabolism, which also naturally reduces ROS formation. This hypothesis is further supported by the significant reduction in ETS activities at almost all sulfoxaflor concentrations, which may in fact point towards an activity reduction in a very early and low concentration stage, which may influence the myriad of responses addressed in this study, making their interpretation increasingly complex. However, further in time, and due to continuous exposure, there is already evidence of oxidative damage, as reported for LPO in hepatopancreas and muscle. Benli and Çelik [65] also reported increases in TBARS levels after $96 \mathrm{~h}$ exposure to sulfoxaflor in zebrafish.

The electron transport system (ETS) is a metabolic energy biomarker related to the organism oxygen consumption [32]. In the present study, sulfoxaflor induced a significant decrease in ETS in almost all concentrations from both exposure times, thus revealing a decrease in cellular metabolism. In this context, the reduced ETS activity may be a consequence of organism damaging mechanisms such as oxidative stress, since lipid peroxidation may also exist in the inner mitochondria membrane, damaging it, and consequently impairing metabolism and causing an ETS reduction $[78,79]$. Therefore, the LPO damage assessed in some tissues of $C$. maenas after exposure to sulfoxaflor may influence mitochondria membrane damage, thus altering ETS functions and reducing its activity (as can be seen in PCA T7).

The organism's physiological reaction to stressors is due to its association with the changes in biomarkers endpoints as, for instance, a decrease in behavioural activity could imply a reduced respiration and ETS reduction in this study, which may then greatly limit the oxidative damage demonstrated herein. The interaction between sulfoxaflor concentration magnitude and behavioural responses may underlie the greater difficulty in linking data. Thus, for a better understanding, overview, and interconnection among behavioural and biochemical biomarkers, future studies should include physiological processes, for instance, heart-rate, respiration rates, growth, and reproduction $[15,80]$. Despite further increasing the complexity of endpoints, the present inclusion of several tissues and sampling times contributes to enlighten response interconnection, complexity, and challenge non-monotonicity.

\section{Conclusions}

The present study demonstrated that exposure to sulfoxaflor can affect the non-target coastal invertebrate Carcinus maenas at different levels of biological organisation, with its increasing concentrations, which causes a decrease in detoxification capacity and an increase in oxidative damage, such as LPO, while reductions in energy metabolism were also noticed. Additionally, an impact on motricity and feeding was pronounced. These findings highlight sub-individual endpoints to act as early warning signs that could lead to later and higher biological level effects [81], namely upon exposure to xenobiotic. These integrative approaches deepen the understanding of the potential detrimental effects of contaminants in organisms, and on forthcoming impacts at higher levels of biological organisation. Despite the lack of information related to monitoring sulfoxaflor concen- 
trations in the aquatic environment, detrimental effects were observed for C. maenas at concentrations lower than those found for other studied organisms. Since there are few in vivo studies on the effects of sulfoximine class on non-target species, this study contributes to increase the knowledge on the insecticide sulfoxaflor mode of toxic action and its impacts on coastal/marine invertebrates. Still, additional studies are needed to better comprehend sulfoxaflor's mode of action on crabs and other invertebrates, providing further information on the environmental risks caused by this insecticide in coastal regions where it may be easily found.

Supplementary Materials: The following are available online at https:/ / www.mdpi.com/article/10 $.3390 /$ biology10121234/s1. Figure S1. Biochemical biomarkers responses measured in hepatopancreas and gills of Carcinus maenas after 3 and 7 days of exposure to sulfoxaflor (mean \pm SD), related to detoxification-(a) glutathione S-transferase (GST) measured in hepatopancreas, oxidative stress (b) superoxide dismutase (SOD) and (c) DNA damage (DNAd) measured in hepatopancreas; and (d) DNAd measured in gills. * Indicates statistically significant differences in relation to control, and \# denotes statistically significant differences between exposure time 3 and 7 days $(p<0.05$, GzLM, followed by pairwise comparison method with adjustment to LSD). Only the biomarkers with no significant differences are shown, compared to control, Table S1. Hydrological parameters (mean \pm SD) assessed during acute and sub-lethal tests: temperature; salinity; $\mathrm{pH}$; and $\mathrm{DO}=$ dissolved oxygen. Table S2. Estimated lethal concentration (LCx) for Carcinus maenas after 96h exposure to sulfoxaflor. Table S3. Spearman's correlation among all biomarkers and behavioural responses. Positive or negative significant correlation are highlighted in bold and with asterisks $\left({ }^{*} p\right.$-value $<0.05$, ** $p$-value $<0.01)$. Time of exposure to sulfoxaflor-T3 = exposure time 3 days; T6 = exposure time 6 days; $\mathrm{T} 7$ = exposure time 7 days. Behavioural endpoints assessed-feed intake; motricity. Tissues analysed- $(\mathrm{G})$ = gills; $(\mathrm{H})=$ hepatopancreas; $(\mathrm{M})=$ muscle. Detoxification biomarkersGST = glutathione S-transferase, oxidative stress-SOD = superoxide dismutase; ROS = reactive oxygen species; DNAd = DNA damage; $\mathrm{LPO}=$ lipid peroxidation, energy metabolism-IDH = isocitrate dehydrogenase; LDH = lactate dehydrogenase; ETS = electron transport system, and neuromuscular toxicity- AChE = acetylcholinesterase.

Author Contributions: Conceptualization, J.M.D., L.D.R., S.C.N. and M.F.L.L.; methodology, J.M.D., L.D.R., T.S., S.C.N. and M.F.L.L.; validation, J.M.D., S.C.N. and M.F.L.L.; formal analysis, J.M.D., L.D.R. and S.C.N.; investigation, J.M.D., L.D.R., T.S., I.F.C.M. and G.M.; resources, S.C.N. and M.F.L.L.; data curation, J.M.D., L.D.R. and S.C.N.; writing—original draft preparation, J.M.D.; writing—review and editing, J.M.D., L.D.R., T.S., S.C.N. and M.F.L.L.; visualization, J.M.D. and L.D.R.; supervision, S.C.N. and M.F.L.L.; project administration, M.F.L.L.; funding acquisition, M.F.L.L. All authors have read and agreed to the published version of the manuscript.

Funding: This study had the support of Fundação para a Ciência e a Tecnologia (FCT) through the Strategic Project UID/MAR/04292/2020 grants to MARE, project MARINE INVADERS-The impact and mechanisms of success of the invasive seaweed Asparagopsis armata on coastal environments (POCI-01-0145-FEDER-031144), and grant awarded to Lénia Rato (SFRH/BD/138492/2018). The project was also partially funded by "Global Invaders-Global trends among valued aquatic invertebrate species: competitive advantages across different latitudes" funded by FCT and DAADDeutscher Akademischer Austauschdienst. Sara Novais is funded by national funds (OE), through FCT-Fundação para a Ciência e a Tecnologia, I.P., in the scope of the framework contract foreseen in the numbers 4, 5 and 6 of the article 23, of the Decree-Law 57/2016, of 29 August, changed by Law 57/2017, of 19 July.

Institutional Review Board Statement: Not applicable.

Informed Consent Statement: Not applicable.

Data Availability Statement: On reasonable request, all data can be received from the corresponding authors.

Acknowledgments: The help of the fishermen who collected the Carcinus maenas in Óbidos lagoon, Portugal.

Conflicts of Interest: The authors declare no conflict of interest. 


\section{References}

1. Mateo-Sagasta, J.; Zadeh, S.M.; Turral, H.; Burke, J. Water Pollution from Agriculture: A Global Review; FAO: Rome, Italy; IWMI: Colombo, Sri Lanka, 2017. Available online: https://www.fao.org/3/i7754e/i7754e.pdf (accessed on 12 May 2021).

2. Singh, B.; Kaur, A. Control of insect pests in crop plants and stored food grains using plant saponins: A review. LWT-Food Sci. Technol. 2018, 87, 93-101. [CrossRef]

3. Gonçalves, A.M.M.; Rocha, C.P.; Marques, J.C.; Gonçalves, F.J.M. Enzymes as useful biomarkers to assess the response of freshwater communities to pesticide exposure-A review. Ecol. Indic. 2021, 122, 107303. [CrossRef]

4. Zhu, Y.; Loso, M.R.; Watson, G.B.; Sparks, T.C.; Rogers, R.B.; Huang, J.X.; Gerwick, B.C.; Babcock, J.M.; Kelley, D.; Hegde, V.B.; et al. Discovery and characterization of sulfoxaflor, a novel insecticide targeting sap-feeding pests. J. Agric. Food Chem. 2011, 59, 2950-2957. [CrossRef]

5. Aktar, W.; Sengupta, D.; Chowdhury, A. Impact of pesticides use in agriculture: Their benefits and hazards. Interdiscip. Toxicol. 2009, 2, 1-12. [CrossRef] [PubMed]

6. Babu, V.; Unnikrishnan, P.; Anu, G.; Nair, S.M. Distribution of organophosphorus pesticides in the bed sediments of a backwater system located in an agricultural watershed: Influence of seasonal intrusion of seawater. Arch. Environ. Contam. Toxicol. 2011, 60, 597-609. [CrossRef]

7. Sharma, A.; Kumar, V.; Shahzad, B.; Tanveer, M.; Sidhu, G.P.S.; Handa, N.; Kohli, S.K.; Yadav, P.; Bali, A.S.; Parihar, R.D.; et al. Worldwide pesticide usage and its impacts on ecosystem. SN Appl. Sci. 2019, 1, 1446. [CrossRef]

8. Dow AgroSciences. Isoclast ${ }^{\mathrm{TM}}$ active Technical Bulletin; Dow AgroSciences: Indianapolis, IN, USA, 2014. Available online: https:/ / www.corteva.com/content/dam/dpagco/corteva/global/corporate/general/files/active-ingredients/DF_IsoclastActive-TechBulletin_LO7_2019.pdf (accessed on 15 April 2021).

9. Babcock, J.M.; Gerwick, C.B.; Huang, J.X.; Loso, M.R.; Nakamura, G.; Nolting, S.P.; Rogers, R.B.; Sparks, T.C.; Thomas, J.; Watson, G.B.; et al. Biological characterization of sulfoxaflor, a novel insecticide. Pest Manag. Sci. 2010, 67, 328-334. [CrossRef]

10. Sparks, T.C.; Watson, G.B.; Loso, M.R.; Geng, C.; Babcock, J.M.; Thomas, J.D. Sulfoxaflor and the sulfoximine insecticides: Chemistry, mode of action and basis for efficacy on resistant insects. Pestic. Biochem. Physiol. 2013, 107, 1-7. [CrossRef]

11. Watson, G.B.; Loso, M.R.; Babcock, J.M.; Hasler, J.M.; Letherer, T.J.; Young, C.D.; Zhu, Y.; Casida, J.E.; Sparks, T.C. Novel nicotinic action of the sulfoximine insecticide sulfoxaflor. Insect Biochem. Mol. Biol. 2011, 41, 432-439. [CrossRef]

12. Siviter, H.; Brown, M.J.F.; Leadbeater, E. Sulfoxaflor exposure reduces bumblebee reproductive success. Nature 2018, 561, 109-112. [CrossRef]

13. Gauthier, J.R.; Mabury, S.A. Sulfoximine Insecticide Sulfoxaflor and its Photodegradate Demonstrates Acute Toxicity to Nontargeted Invertebrate Species Daphnia magna. Environ. Toxicol. Chem. 2021, 40, 2156-2164. [CrossRef]

14. Lionetto, M.G.; Caricato, R.; Giordano, M.E. Pollution Biomarkers in Environmental and Human Biomonitoring. Open Biomark. J. 2019, 9, 1-9. [CrossRef]

15. Rodrigues, E.T.; Pardal, M.Â. The crab Carcinus maenas as a suitable experimental model in ecotoxicology. Environ. Int. 2014, 70, 158-182. [CrossRef] [PubMed]

16. Klassen, G.J.; Locke, A. A Biological Synopsis of the European Green Crab, Carcinus Maenas; Fisheries and Oceans Canada: Moncton, NB, Canada, 2007; pp. 1-82.

17. Young, A.M.; Elliott, J.A. Life History and Population Dynamics of Green Crabs (Carcinus maenas). Fishes 2020, 5, 4. [CrossRef]

18. Chen, C.H. Activation and Detoxification Enzymes: Functions and Implications, 1st ed.; Springer: New York, NY, USA, 2012. [CrossRef]

19. Liska, D.A.J. The detoxification enzyme systems. Altern. Med. Rev. 1998, 3, 187-198. [PubMed]

20. Boyland, E.; Chasseaud, L.F. The role of glutathione and glutathione S-transferases in mercapturic acid biosynthesis. Adv. Enzymol. Relat. Areas Mol. Biol. 1969, 32, 173-219. [CrossRef]

21. Di Giulio, R.T.; Washburn, P.C.; Wenning, R.J. Biochemical responses in aquatic animals: A review of determinants of oxidative stress. Environ. Toxicol. Chem. 1989, 8, 1103-1123. [CrossRef]

22. Novais, S.C.; Gomes, N.C.; Soares, A.M.V.M.; Amorim, M.J.B. Antioxidant and neurotoxicity markers in the model organism Enchytraeus albidus (Oligochaeta): Mechanisms of response to atrazine, dimethoate and carbendazim. Ecotoxicology 2014, 23, 1220-1233. [CrossRef]

23. Schittenhelm, D.; Neuss-Radu, M.; Verma, N.; Pink, M.; Schmitz-Spanke, S. ROS and pentose phosphate pathway: Mathematical modelling of the metabolic regulation in response to xenobiotic-induced oxidative stress and the proposed Impact of the gluconate shunt. Free Radic. Res. 2019, 53, 979-992. [CrossRef] [PubMed]

24. Thannickal, V.J.; Fanburg, B.L. Reactive oxygen species in cell signaling. Am. J. Physiol.-Lung Cell. Mol. Physiol. 2000, 279, L1005-L1028. [CrossRef]

25. Regoli, F.; Giuliani, M.E. Oxidative pathways of chemical toxicity and oxidative stress biomarkers in marine organisms. Mar. Environ. Res. 2014, 93, 106-117. [CrossRef]

26. Holmblad, T.; Söderhäll, K. Cell adhesion molecules and antioxidative enzymes in a crustacean, possible role in immunity. Aquaculture 1999, 172, 111-123. [CrossRef]

27. Mohankumar, K.; Ramasamy, P. White spot syndrome virus infection decreases the activity of antioxidant enzymes in Fenneropenaeus indicus. Virus Res. 2006, 115, 69-75. [CrossRef] [PubMed]

28. Sancho, E.; Villarroel, M.J.; Andreu, E.; Ferrando, M.D. Disturbances in energy metabolism of Daphnia magna after exposure to tebuconazole. Chemosphere 2009, 74, 1171-1178. [CrossRef] 
29. Diamantino, T.C.; Almeida, E.; Soares, A.M.V.M.; Guillermino, L. Lactate dehydrogenase activity as an effect criterion in toxicity tests with Daphnia magna strauss. Chemosphere 2001, 45, 553-560. [CrossRef]

30. Lima, I.; Moreira, S.M.; Osten, J.R.V.; Soares, A.M.V.M.; Guilhermino, L. Biochemical responses of the marine mussel Mytilus galloprovincialis to petrochemical environmental contamination along the North-western coast of Portugal. Chemosphere 2007, 66, 1230-1242. [CrossRef]

31. Tonn, N.; Novais, S.C.; Silva, C.S.E.; Morais, H.A.; Correia, J.P.S.; Lemos, M.F.L. Stress responses of the sea cucumber Holothuria forskali during aquaculture handling and transportation. Mar. Biol. Res. 2016, 12, 948-957. [CrossRef]

32. De Coen, W.; Janssen, C.R. The use of biomarkers in Daphnia magna toxicity testing. IV. Cellulst Energy Allocation: A new methodology to assess the energy budget of toxicant-stressed Daphinia populations. J. Aquat. Ecosyst. Stress Recover. 1997, 6, 43-55. [CrossRef]

33. Sturm, A.; Da Silva De Assis, H.C.; Hansen, P.D. Cholinesterases of marine teleost fish: Enzymological characterization and potential use in the monitoring of neurotoxic contamination. Mar. Environ. Res. 1999, 47, 389-398. [CrossRef]

34. Directive 2010/63/EU of the European Parliament and of the Council of 22 September 2010, protection of animals used for scientific purposes. Off. J. Eur. Union 2010, L276, 33-79.

35. Decreto-Lei 113/2013, de 7 de agosto. Diário da República $1^{a}$ série; Ministério da Agricultura, do Mar, do Ambiente e do Ordenamento do Território: Lisboa, Portugal, 2013; pp. 4709-4739.

36. Durand, F.; Regnault, M. Nitrogen metabolism of two portunid crabs, Carcinus maenas and Necora puber, during prolonged air exposure and subsequent recovery: A comparative study. J. Exp. Biol. 1998, 201, 2515-2528. [CrossRef]

37. ASTM International. Standard Guide for Conducting Acute Toxicity Tests on Tests Materials with Fishes, Macroinvertebrates, and Amphibians; ASTM International: West Conshohocken, PA, USA, 2002; Volume 96, pp. 1-22.

38. MARETEC. Programa de Monitorização da Lagoa de Óbidos e do Emissário Submarino da Foz do Arelho. Caracterização da Situação de Referência: Qualidade da Água da Lagoa de Óbidos. 2004, p. 57. Available online: http://maretec.mohid.com/ projects / fozdoarelho/Relatorios/2004-2005/Rel_02_Modela\%C3\%A7\%C3\%A3o\%20da\%20Qualidade\%20da\%20Agua.pdf. (accessed on 4 December 2020).

39. Rodrigues, E.T.; Moreno, A.; Mendes, T.; Palmeira, C.; Pardal, M.Â. Biochemical and physiological responses of Carcinus maenas to temperature and the fungicide azoxystrobin. Chemosphere 2015, 132, 127-134. [CrossRef]

40. Yue, S. The Welfare of Crustaceans at Slaughter. Impacts Farm Anim. 2008, 5, 10. Available online: https://animalstudiesrepository. org/hsus_reps_impacts_on_animals/4 (accessed on 23 April 2020).

41. Oliveira, D.N.; Christofoletti, R.A.; Barreto, E.R. Feeding behavior of a crab according to cheliped number. PLoS ONE 2015, 10, e0145121. [CrossRef]

42. Van den Brink, A.; Hutting, S. Clash of the crabs: Interspecific, inter-cohort competition between the native European green crab, Carcinus maenas and the exotic brush clawed crab Hemigrapsus takanoi on artificial oyster reefs. J. Sea Res. 2017, 128, 41-51. [CrossRef]

43. Abreu, I.O.; Monteiro, C.; Rocha, A.C.S.; Reis-Henriques, M.A.; Teixeira, C.; Basto, M.C.P.; Ferreira, M.; Almeida, C.M.R.; Oliva-Teles, L.; Guimarães, L. Multibiomarker interactions to diagnose and follow-up chronic exposure of a marine crustacean to Hazardous and Noxious Substances (HNS). Environ. Pollut. 2018, 242, 1137-1145. [CrossRef] [PubMed]

44. Bradford, M.M. A rapid and sensitive method for the quantitation of microgram quantities of protein utilizing the principle of protein-dye binding. Anal. Biochem. 1976, 72, 248-254. [CrossRef]

45. Ellis, G.; Goldberg, D.M. An improved manual and semi-automatic assay for NADP-dependent isocitrate dehydrogenase activity, with a description of some kinetic properties of human liver and serum enzyme. Clin. Biochem. 1971, 2, 175-185. [CrossRef]

46. Vassault, A.; Wahlfold, A.W.; Deneke, U. Lactate Dehydrogenasein in Methods of Enzymatic Analysis, 3rd ed.; Bergmeyer, H.U., Bergmeyer, J., GraB 1, M., Moss, D.W., Eds.; Verlag Chemie: Weinheim, Germany, 1983; Volume 3, pp. 118-126.

47. Habig, W.H.; Pabst, M.J.; Jakoby, W.B. Glutathione S-Transferases-First enzymatic step in mercapturic acid formation. J. Biol. Chem. 1974, 7130-7139. [CrossRef]

48. Socci, D.J.; Bjugstad, K.B.; Jones, H.C.; Pattisapu, J.V.; Arendash, G.W. Evidence that oxidative stress is associated with the pathophysiology of inherited hydrocephalus in the H-Tx rat model. Exp. Neurol. 1999, 155, 109-117. [CrossRef]

49. McCord, J.M.; Fridovich, I. Superoxide dismutase. An enzymic function function for erythrocuprein (hemocuprein). J. Biol. Chem. 1969, 244, 6049-6055. [CrossRef]

50. Bird, R.P.; Draper, A.H. Comparative studies on different methods of malonaldehyde determination. Methods Enzym. 1984, 105, 299-305. [CrossRef]

51. Ohkawa, H.; Ohishi, N.; Yagi, K. Assay for lipid peroxides in animal tissues by thiobarbituric acid reaction. Anal. Biochem. 1979, 95, 351-358. [CrossRef]

52. Torres, M.A.; Testa, C.P.; Gáspari, C.; Masutti, M.B.; Panitz, C.M.N.; Curi-Pedrosa, R.; De Almeida, E.A.; Di Mascio, P.; Filho, D.W. Oxidative stress in the mussel Mytella guyanensis from polluted mangroves on Santa Catarina Island, Brazil. Mar. Pollut. Bull. 2002, 44, 923-932. [CrossRef]

53. Olive, P.L. DNA precipitation assay: A rapid and simple method for detecting DNA damage in mammalian cells. Environ. Mol. Mutagen 1988, 11, 487-495. [CrossRef] [PubMed]

54. De Lafontaine, Y.; Gagné, F.; Blaise, C.; Costan, G.; Gagnon, P.; Chan, H.M. Biomarkers in zebra mussels (Dreissena polymorpha) for the assessment and monitoring of water quality of the St Lawrence River (Canada). Aquat. Toxicol. 2000, 50, 51-71. [CrossRef] 
55. Ellman, G.L.; Courtney, K.D., Jr. Andres, V.; Featherstone, R.M. A new and rapid colorimetric determination of acetylcholinesterase activity. Biochem. Pharmacol. 1961, 2, 88-95. [CrossRef]

56. Guilhermino, L.; Lopes, M.C.; Carvalho, A.P.; Soares, A.M.V.M. Inhibition of acetylcholinesterase activity as effect criterion in acute tests with juvenile Daphinia magna. Chemosphere 1996, 32, 727-738. [CrossRef]

57. Zar, J.H. Biostatistical Analysis, 5th ed.; Pearson: Upper Saddle River, NJ, USA, 2010; ISBN 9780131008465.

58. Zuur, A.F.; Ieno, E.N.; Smith, G.M. Analysing Ecological Data; Springer: Berlin/Heidelberg, Germany, 2007; ISBN 9780387459677.

59. Ho, R. Multivariate Data Analysis with IBM SPSS; CRC Press: Boca Raton, FL, USA, 2008; ISBN 9781439890226.

60. Lepš, J.; Šmilauer, P. Multivariate Analysis of Ecological Data Using CANOCO; Cambridge University Press: Cambridge, NY, USA, 2003; ISBN 9780521814096.

61. Morrissey, C.A.; Mineau, P.; Devries, J.H.; Sanchez-Bayo, F.; Liess, M.; Cavallaro, M.C.; Liber, K. Neonicotinoid contamination of global surface waters and associated risk to aquatic invertebrates: A review. Environ. Int. 2015, 74, 291-303. [CrossRef]

62. Gibbons, D.; Morrissey, C.; Mineau, P. A review of the direct and indirect effects of neonicotinoids and fipronil on vertebrate wildlife. Environ. Sci. Pollut. Res. 2015, 22, 103-118. [CrossRef]

63. Siviter, H.; Horner, J.; Brown, M.J.F.; Leadbeater, E. Sulfoxaflor exposure reduces egg laying in bumblebees Bombus terrestris. J. Appl. Ecol. 2020, 57, 160-169. [CrossRef]

64. Niesen, M.; Sappington, K.; Ruhman, M.; Mroz, R.; Leader, R.A.P.; Housenger, J.; Chief, B. Ecological Risk Assessment for the Registration Review of Sulfoxaflor; United States Environmental Protection Agency: Washington, DC, USA, 2019 ; pp. 1-286.

65. Benli, P.P.; Çelik, M. Glutathione and its dependent enzymes' modulatory responses to neonicotinoid insecticide sulfoxaflor induced oxidative damage in zebrafish in vivo. Sci. Prog. 2021, 104, 368504211028361. [CrossRef]

66. Benli, P.P.; Çelik, M. In Vivo effects of neonicotinoid-sulfoximine insecticide sulfoxaflor on acetylcholinesterase activity in the tissues of Zebrafish (Danio Rerio). Toxics 2021, 9, 73. [CrossRef]

67. Watts, A.J.R.; Urbina, M.A.; Corr, S.; Lewis, C.; Galloway, T.S. Ingestion of Plastic Microfibers by the Crab Carcinus maenas and Its Effect on Food Consumption and Energy Balance. Environ. Sci. Technol. 2015, 49, 14597-14604. [CrossRef]

68. Dissanayake, A.; Piggott, C.; Baldwin, C.; Sloman, K.A. Elucidating cellular and behavioural effects of contaminant impact (polycyclic aromatic hydrocarbons, PAHs) in both laboratory-exposed and field-collected shore crabs, Carcinus maenas (Crustacea: Decapoda). Mar. Environ. Res. 2010, 70, 368-373. [CrossRef]

69. Rodrigues, A.P.; Lehtonen, K.K.; Guilhermino, L.; Guimarães, L. Exposure of Carcinus maenas to waterborne fluoranthene: Accumulation and multibiomarker responses. Sci. Total Environ. 2013, 443, 454-463. [CrossRef] [PubMed]

70. Reddy, S.L.N.; Venugopal, N.B.R.K. Effect of fluoride on acetylcholinesterase activity and oxygen consumption in a freshwater field crab, Barytelphusa guerini. Bull. Environ. Contam. Toxicol. 1990, 45, 760-766. [CrossRef]

71. Silva, C.O.; Simões, T.; Félix, R.; Soares, A.M.V.M.; Barata, C.; Novais, S.C.; Lemos, M.F.L. Asparagopsis armata exudate cocktail: The quest for the mechanisms of toxic action of an invasive seaweed on marine invertebrates. Biology 2021, 10, 223. [CrossRef]

72. Qi, S.; Wang, D.; Zhu, L.; Teng, M.; Wang, C.; Xue, X.; Wu, L. Neonicotinoid insecticides imidacloprid, guadipyr, and cycloxaprid induce acute oxidative stress in Daphnia magna. Ecotoxicol. Environ. Saf. 2018, 148, 352-358. [CrossRef]

73. Bacci, L.; Convertini, S.; Rossaro, B. A review of sulfoxaflor, a derivative of biological acting substances as a class of insecticides with a broad range of action against many insect pests. J. Entomol. Acarol. Res. 2018, 50, 51-71. [CrossRef]

74. Livingstone, D.R. Oxidative stress in aquatic organisms in relation to pollution and aquaculture. Rev. Med. Vet. 2003, 154, 427-430

75. Shukla, S.; Jhamtani, R.C.; Dahiya, M.S.; Agarwal, R. Oxidative injury caused by individual and combined exposure of neonicotinoid, organophosphate and herbicide in zebrafish. Toxicol. Rep. 2017, 4, 240-244. [CrossRef] [PubMed]

76. Vieira, C.E.D.; Pérez, M.R.; Acayaba, R.D.A.; Raimundo, C.C.M.; dos Reis Martinez, C.B. DNA damage and oxidative stress induced by imidacloprid exposure in different tissues of the Neotropical fish Prochilodus lineatus. Chemosphere 2018, 195, 125-134. [CrossRef] [PubMed]

77. Yan, S.H.; Wang, J.H.; Zhu, L.S.; Chen, A.M.; Wang, J. Thiamethoxam induces oxidative stress and antioxidant response in zebrafish (Danio Rerio) livers. Environ. Toxicol. 2016, 31, 2006-2015. [CrossRef] [PubMed]

78. Stolze, K.; Nohl, H. Effect of xenobiotics on the respiratory activity of rat heart mitochondria and the concomitant formation of superoxide radicals. Environ. Toxicol. Chem. 1994, 13, 499-502. [CrossRef]

79. Choi, J.; Roche, H.; Caquet, T. Hypoxia, hyperoxia and exposure to potassium dichromate or fenitrothion alter the energy metabolism in Chironomus riparius Mg. (Diptera: Chironomidae) larvae. Comp. Biochem. Physiol.-C Toxicol. Pharmacol. 2001, 130, 11-17. [CrossRef]

80. Depledge, M.H.; Aagaard, A.; Györkös, P. Assessment of trace metal toxicity using molecular, physiological and behavioural biomarkers. Mar. Pollut. Bull. 1995, 31, 19-27. [CrossRef]

81. Lemos, M.F.L.; Soares, A.M.V.M.; Correia, A.C.; Esteves, A.C. Proteins in ecotoxicology-How, why and why not? Proteomics 2010, 10, 873-887. [CrossRef] 